\title{
Predictors of Branding and the Role of Warranty on Consumer Choice
}

\author{
J.C. Blewitt ${ }^{1}$ \\ ${ }^{1}$ McGowan School of Business, King's College, Wilkes-Barre, PA, United States \\ Correspondence: J.C. Blewitt, McGowan School of Business, 133 N. River St. Wilkes-Barre, PA 18711, United \\ States.
}

Received: June 21, 2018

doi:10.5539/ibr.v11n8p122

\author{
Accepted: July 14, 2018 \\ Online Published: July 19, 2018 \\ URL: https://doi.org/10.5539/ibr.v11n8p122
}

\begin{abstract}
This conceptual paper reviews the literature from three distinct areas in consumer behavior: branding, warranty, and choice. In using a mixture of these three areas, propositions are developed which will be tested in future research. The impact of this study is geared towards understanding the behavior of consumers purchasing high cost items and the relative importance and trust that is placed in the warranty that comes with such a purchase. While the study will consider domestic (United States) consumers, international factors such as country of origin and psychic distance will be posed as viable factors in the decision making process. We propose that six factors will impact the role of branding in the decision making process and that a warranty will serve as a moderator to the ultimate choice decision.
\end{abstract}

Keywords: branding, warranty, consumer behavior, country of origin, psychic distance

\section{Introduction}

A common expression in business is that a warranty is only as good as the company's reputation that stands behind it. Everyday consumers purchasing everyday goods probably don't think much about warranties when making a grocery store or pharmacy run, but when it comes to large-scale purchases like automobiles, appliances, televisions, and other big ticket items, a warranty can become a make-or-break factor in the decision-making process. In fact, warranties have become competitive advantages to some firms (Xie, 2017). Various brands offer similar warranties in terms of length, coverage, and quality. The purpose of this research is to examine predictors of branding and the role of a warranty on purchase decisions. The paper proceeds as follows. To begin, a literature review is conducted on branding, warranty, and choice theory. Propositions to be tested in a forthcoming empirical study will be posited throughout this literature review. Next, a discussion of additional branding factors and their corresponding literature is examined, and further propositions are posited. These additional factors include reputation, national exposure, country of origin, emotional appeal, ease of product recall, and psychic distance. Following this section, some frameworks are proposed based on the theory developed throughout this conceptual paper. Finally, some managerial implications and conclusions are discussed.

\section{Literature Review}

\subsection{Branding}

"If a company is able to make a consumer look at a certain product for a fraction of a second longer than its competitors' products, the probability of purchase intent increases significantly (Sandom 2008)." A recent New York Times article describing people's frustration with advertisements being everywhere cite a study done by Yankelovich, Inc., a market research firm, which has claimed that 30 years ago, people living in a city would see up to 2,000 advertisements in one day. That figure has more than doubled in today's marketplace; city dwellers can be exposed to up to 5,000 advertisements daily (Story, 2007)! While there is no need for an agreement on the actual number of ads an individual is exposed to on a given day, it can be agreed that the amount of advertising a person is exposed to in a short amount of time can be staggering. Advertising is a method used by companies which attempts to gain name recognition and credibility in the market (Petty, Cacioppo, \& Schumann, 1983). Advertising is a portion of the study of branding, which has been given considerable attention in consumer behavior research for the past half-century or more. In a recent 2008 article which examines the "laws of branding", T.H. Walvis defined branding as "the activity by brand owners of associating the brand name with those pieces of information, meanings, emotions, images, and intentions that are of key importance in the 
decision-making process of customers and of stakeholders in general" (Walvis, 2008). Each year, the American Brands Council publishes a volume which describes America's greatest brands insomuch as they provide the consumer with an "intrinsic, emotional link". This link is what creates in the consumer the loyalty towards that brand and keeps a person coming back again and again to that product or firm (American Brand Council, 2010). Thus, corporations wishing to establish and maintain a positive and on-going relationship with their customers need to employ a branding strategy that aligns with their business model and appeals to the emotions and habits of their target market. The following subsections discuss a few aspects of branding which will be utilized in building the theoretical framework for this study.

\subsubsection{Attitude Toward the Brand and Brand Association}

Risk adverse consumers, especially when buying high-cost and high-importance items, will be more likely to stick to longstanding and reputable brand names when given the choice between something new and something trusted (Tversky \& Kahneman, 1986). Thus, new entrants go great lengths to pump the consumer pool with advertisements and information about their products, and many times, their warranty, which will back up the message they are communicating. They do this to establish a positive attitude towards the brand, and ultimately influence the consumer decision (Mitchell \& Olson, 1981). Thus, branding can be thought of as an activity which is aimed at increasing the likelihood that a brand is chosen by a customer (Walvis, 2008). In a sense, brands compete with each other for recognition and for position in the consumer's brain.

Corporations across the globe use their corporate brand to gain instant recognition and association of its reputation and goodwill in the consumer's eyes (Rooney, 1995). Such reputations are typically built over a considerable time period, and often times a major stumbling block for new brands is that customers have reluctance to something new and unknown. Marketing research has demonstrated that an organization's reputation will affect a consumer's product choice, intentions for purchases, and overall attitude towards the brand (Hess, 2008; Johnson \& Grayson, 2005). Consumers use their attitudes, persistent outlooks on a given stimuli, to organize their thoughts about the product or service or to retrieve associated thoughts and feelings about the brand. Marketers use brand associations and attitudes to differentiate product offerings, create positive word of mouth, and to promote the attributes of a specific product offering (Aaker, 1991). For example, Hyundai motors, in the last several years, has shifted its product offering from a base-model company to now one that includes luxury features and attributes on the level of other mid-range automobiles such as Honda, Chrysler, and Volkswagen. The company has made an effort to re-position itself in the market, and thus, consumers' attitude towards the brand has shifted. However, whether or not consumers are aware of this shift can play a major role in their choice decision. There has been vast empirical research which has shown that brand associations differ across product categories (Low \& Lamb, 2000). This may be due to attributes of the product, their costs, the customer's involvement, or even some of the dimensions identified by Hofstede such as long-term orientation or collectivism (Hofstede, 1991). One of the most vivid examples of brand association would be Wal-Mart and its association with low price. If a consumer's brand association does not accurately assess the company's offering or position, marketing managers need to make efforts to revise the association.

\subsubsection{Perception of the Brand}

Perception by the consumer is another piece of the branding effort which must be understood to grasp the importance of branding for a firm. Perceived quality is defined as the consumer's judgment about a product's overall excellence or superiority (Aaker \& Jacobson, 1994; Zeithaml, 1988). Strong brands add value to consumers' purchase evaluations. In a relevant study, Sethuraman and Cole illustrated that perceived quality "explains a considerable portion of the variance in the price premium consumers are willing to pay for brands" (Sethuraman \& Cole, 1997). For example, Volkswagen's quality may be perceived as very high since it is a Germany company and many other high quality automobile makers originate there. In addition, German manufacturing has a perceived high level of manufacturing know-how and the country, in general, employs the highest quality standards in the world. These factors may have a significant impact on the perceived quality offering by Volkswagen. This phenomenon is also part of the Country of Origin effect, which will be examined in a following section.

McClure et al. in a 2004 study, tested the impact of branding on American consumers in a taste test between Coca-Cola and Pepsi. While both of these brands can confidently be considered household names, the longer history and "American" reputation of Coca-Cola resonated. In a blind taste test, around half of their respondents selected Pepsi over Coca-Cola, but when given a choice between the two products when knowing their identity, nearly $75 \%$ of all the respondents preferred the Coca-Cola brand (McClure et al., 2004). This groundbreaking discovery illustrates that preferences can be overridden by branding effects, specifically perception. The 
long-term association of Coca-Cola on a significant percentage of consumers has caused them to not follow their taste preferences, but rather follow the better known product offering.

This discussion of branding and the classic case-study on Coca-Cola versus Pepsi leads us to a few conclusions. First, in establishing a reputation and determining core competencies, companies seek to gain an emotional buy-in by their target market. This is emotional branding, which has been defined as "a consumer-centric, relational, and story-driven approach to forging deep and enduring affective bonds between consumers and brands" (Roberts, 2004). When brands are able to create an emotional connection with a consumer through attitude and perception formation, there is a sense of loyalty which resonates within that person and causes them to decide on a brand that they have a connection with, even if their tastes or instant appeal is towards a competing brand (Keller, 2003). We expect this finding to ring true in this analysis and thus, it leads us to the following propositions:

- Proposition 1 - Consumers will be more likely to choose a brand which has a more established reputation when it comes to large-scale purchases.

- Proposition 2 - The greater the efforts of a company to create an emotional brand linkage, the stronger the branding effect.

\subsection{Warranty}

As alluded to in the introduction, warranties can be thought of as a guarantee behind the product that one is purchasing (Day \& Fox, 1985). It is the company assuring the customer that their product will meet or exceed their expectation or they will rectify the situation to the customer's satisfaction. Warranties can be used as a profit-making tool since many firms sell them as a supplement to the product (for example, extended warranties on iPods or Televisions), or they can be used to retain customers by remedying problems that the consumer encounters (Day \& Fox, 1985). In terms of a profit making endeavor, warranties appear to be a great source of additional revenue for a firm with relatively little risk. In a 2001 paper by Noel, the author shows that warranties are rarely invoked or utilized despite the consumer's willingness to pay more money for the extended coverage (Noel, 2001).

A consumer should keep in mind three factors when deciding on a product warranty: perceived risk, personal risk aversion, and magnitude of the purchase. Perceived risk is a major theme across the literature on warranty since they provide consumers with a sort of insurance which protects them from losing their original investment (Kelley \& Conant, 1987). Other factors include the consumer's level of risk aversion, the failure rate of the product, and the price of that warranty (Albaum \& Wiley, 2010). In their 1992 article, authors Voss and Ahmed determined three types of consumers who would be wise to purchase an additional warranty of a product or service: those who were very risk averse, those who have prior losses in the product category, and those who use a price-seeking strategy (Voss \& Ahmed, 1992). A common pitfall for many consumers in terms of warranties on short-term items is that paperwork is lost or there is confusion as to who is providing the warranty. Large-scale purchases are a little different, in a sense that warranties are typically easier to implement (Shuptrine \& Moore, 1980). The consumer will simply take the item or call the location where he or she purchased, and they will fix the warranty-covered problem or advise the consumer regarding the next step in enacting their warranty. Failing to provide warranty performance will have a negative impact on the consumer's view of the product and their satisfaction with the brand will plummet (Albaum \& Wiley, 2010). While prior works have looked at the effect of a warranty and its associated "optimal menu for warranty coverage" (Padmanabhan \& Roa, 1993), this paper seeks to be more of a guide for marketers in showing that customer perceptions of their firm's warranty offerings may be viewed by consumers in a distinct light considering a number of factors.

Consumers value the benefits of warranties and are not particularly concerned with who provides the maintenance, just that it gets done (Albaum \& Wiley, 2010). In consumer behavior, satisfaction is defined as the comparison between the perceived value of a product and the actual value obtained by the customer from that product (Churchill \& Suprenant, 1982). Thus, warranties can be looked upon as satisfaction enhancers if implemented correctly. The main hypothesis of this paper proposes that warranty is a moderator of the branding effort and will play a significant role in the selection of a product. The proposition listed below will be tested in order to gain a more comprehensive understanding of the impact of the warranty on the consumer's purchasing decision.

- Proposition 3 - Warranty will moderate the relationship between attitude/perception and purchase choice. 


\subsection{Choice}

The following sections will examine the literature in choice theory and discuss the implications which guide a consumer's decision-making process. Special attention is directed on large-scale purchases since this category of products will be tested in our forthcoming empirical study. The most classic theory utilized in choice research is rational action theory (Gigerenzer \& Goldstein, 1996). We will begin our discussion of choice here and then consider bounded rationality as another theory which can guide consumers in their decisions on large-scale purchases. Finally, we will discuss an emergent theory of choice in which an overload of options and attributes may be detrimental to the consumer's decision-making process. We anticipate that bounded rationality will guide most consumers in their decisions when it comes to large-scale purchases.

\subsubsection{Rational Choice Theory}

A key principle in society is rationality. It appears as though people strive to make rational decisions in their everyday lives to better themselves, their family, and from a religious perspective, even their soul. This assumption is the central premise upon which rational choice theory lies upon (George, 1998). Traditional economic theory dating back to the 1950s postulates that a consumer is an economic being and thus operates under a set of principles and preferences that are rational in his or her decision making process (Simon, 1955). Individuals will maximize their rewards or benefits from a decision to increase utility (Altonji, Fumio, \& Kotlikoff, 1992; Blau, 1964; Coleman, 1998; Cox \& Rank, 1993). Despite prevalent themes in American society such as overspending, lack of saving, indulgence, and other poor financial behaviors, people attempt to act as rationally as possible when considering large purchases (Tversky \& Simonson, 1993). Thus, the consumer will weigh several options with the outcome of the maximum possible net benefit at the core of the matter. While the degree to which a consumer is a "maximizer" when it comes to decisions varies, present day American society has afforded consumers to have a vast array of options in almost all product and service decisions.

Snow and Oliver, in a 1995 article on consumer behavior, developed three elements that can be used to calculate the net benefit by a consumer. First, there is the actual value of the benefits to be reaped as a result of the choice (Snow \& Oliver, 1995). The customer, based on importance to him or her (or his or her family), will assign a certain value to product attributes. Warranty is an aspect that should be given significant consideration here, particularly in a large purchase decision. Next, the consumer will consider the cost associated with a particular choice. Things to consider here would be the amount of debt he or she will be required to take on or the amount of money per annum that is required to support this product or service. Finally, the consumer will take into account the opportunity cost associated with making the purchase (Snow \& Oliver, 1995). In big-ticket purchases, this might be the forgone benefit of putting an addition onto one's home, sending children to private school, or the lost investment opportunity of money set aside to make this purchase. Opportunity costs need not be related to the actual item (like other competing models or options in that industry), and thus can encompass various facets of one's financial life. Rational consumers will consider these elements in making his or her decision. Rational choice theory assumes that choices are intentional, conscious, and rational (Snow \& Oliver, 1995).

Rational choice is at the individual level. There is no one-set rational choice, but rather a unique and custom solution for each consumer based on the values and weights assigned to each factor in a decision model. From a marketing perspective, one must know what it is that the customer values in order to present an ideal solution for that person (George, 1998). Of course, firms do not specifically advertise and promote to customers on case-by-case basis, but rather they obtain information about a variety of consumer needs and try and meet as many of them as possible within the realm of their product offering. We expect that elements of the warranty such as length of time, ease of use, premium paid for the warranty, country of origin, national psychic distance, and the secure-feeling elicited from the warranty will combine to result in a significant impact on choice.

In closing our discussion on rational choice theory, we believe as though individuals will be hard-pressed to make precisely rational decisions at every turn. A more appropriate theory which has emerged is bounded rationality. This theory is a variation of purely rational decision making, and it is discussed in the following section.

\subsubsection{Bounded Rationality}

In a perfect world, all consumers in all of their purchases would make precisely rational choices every time, with no exceptions. However, this is a naïve assumption to make when considering the seemingly endless possibilities which can skew our rationality. To give one example which has been investigated in the consumer behavior literature stream, Hirschman and Holbrook (1983) look at hedonic consumption and find that in some instances, emotional desires dominate utilitarian motives in the choice of products. Thus, for those consumers who chose 
Pepsi over Coca-Cola in McClure's 2004 experiment, they could have been operating according to hedonic motivation towards their purchase intent, trusting their taste-buds over their preconceived notion of the Coca-Cola brand. Hedonically-experienced products deserve special attention because of their capacity to generate unusually strong emotional involvement (Hirschman \& Holbrook, 1982).

It would be easy to think of many other instances in which a consumer's rational-thinking behavior towards product choice can be skewed. Thus, researchers have developed the bounded rationality theory which guides consumer decisions based on limited time, limited knowledge, and offering complexities (Gigerenzer \& Goldstein, 1996). As alluded to earlier, heuristics and biases can also be part of this "irrational" type of behavior based on personal preferences (Lopes, 1992). Basically, bounded rationality shifts its focus from a consumer making a precisely rational decision to a consumer making a reasonable decision based on accepted limitations (Keeney \& Raiffa, 1993). When it comes to large-scale purchases, consumers will do their best to consider the relevant options and alternatives, but their rationality still may be compromised because of situational factors. For example, if a consumer's washing machine breaks, he or she may not have enough time to consider all of the options since the appliance will need to be replaced within a finite amount of time to keep the family in clean clothing. This would be a large-scale purchase decision and it would be constrained due to limited time. Therefore, the consumer would need to make his or her decision based on bounded rationality. Essentially, a consumer adapts to his or her constraints (time, resources, or complexities) and proceeds to make the most reasonable decision possible out of his or her scenario (Gigerenzer \& Selten, 2002; Simon, 1957). We anticipate that bounded rationality will be the driving theory which directs consumers in their large-scale purchasing decision.

\subsubsection{Emerging Choice Theory}

In a 2004 book entitled "The Paradox of Choice," author Barry Schwartz suggests that the multitude of choices in present day society has actually hindered upon our freedom as members of a free country. He has claimed that having too many options can lead to an overload of information, bad decisions, and even depression (Schwartz, 2004). Schwartz recommends that a consumer creates a personal set of rules for his or her purchases, thus binding his or her rationality at the onset of the decision-making process. An example set of rules for a purchase decision process might look as such: consider three options for a reasonable amount of time, select the most viable one, perform the transaction, move forward confidently in the decision, and spend the most time on the things that are truly important to me (Schwartz, 2004). This is an interesting study and one that may hold a lot of truth moving forward as we encounter more and more options in the consumer experience. Perhaps another type of rationality, building upon bounded rationality, will emerge from these types of studies. Despite this emerging perspective on choice overload and how consumers ought to act in given purchasing scenarios, we assume that this theory has yet to catch on and that the vast majority of consumers in present day society will operate on a bounded rationality basis as discussed by some of the leading authors in this area (Gigerenzer \& Goldstein 1996; Simon 1957).

\subsection{Additional Branding Factors}

The following four subsections will add to the comprehensive understanding of the factors which create the branding effect in a consumer. In addition to creating a reputation and emotional appeal for consumers to invest in the brand as posited in propositions 1 and 2, we expect that four other factors will help explain the branding phenomenon. These factors are ease of product recall, country of origin, psychic distance, and national exposure. Each is examined in the following sections.

\subsubsection{Ease of Product Recall}

Choice researchers often ignore the important element of the consideration set during and prior to evaluation and choice (Nedungadi, 1990). For example, even if a person is not in the market to purchase a new television, he or she may see commercials or other advertisements which promote the latest and greatest products from particular brands. Sony has released many recent commercials which elaborate on their new 3-D LED televisions which are supposed to be some of the most sophisticated and innovative products in the last thirty years. While I am not in the market to be purchasing a television set, I have recalled that entire last statement simply out of memory and brand association with Sony. This is what researchers refer to as a working brand memory, and there is empirical support which suggests that all consumers have a working brand memory which they appeal to in the decision-making process (Alba \& Hasher, 1983; Kahnemann \& Miller, 1986). Certain brands and their product offerings will be able to be retrieved from a consumer's mind even when they are not intending to make a purchase. Thus, when a consumer is actually called to make a decision, those products and brands will be easier to access than others that were not known before encountering the decision process. The working brand memory 
formulation process is dependent upon the frequency, recency, and salience of the brand (Barsalou, 1985; Kintsch \& Young, 1984). In other words, the more times the consumer is exposed to a brand image or specific brand offering, the more likely it is that he or she may consider this brand or product when evaluating a purchase decision. To refer to a somewhat cliché expression, a first impression means everything. Thus, we expect that the ease of product recall will have a direct impact on the branding effort by a particular firm. Once a consumer has a product offering in mind, he or she may be reluctant to consider alternatives or hold an image from his or her working brand memory as the threshold for all other forthcoming considerations. We will examine this effect via the following proposition:

- Proposition 4 - Ease of product recall will have a positive effect on attitude/perception during the decision making process.

\subsubsection{Country of Origin}

Country of Origin (COO) relates to the country in which a product or service originates. A "Country of Origin Effect" has been investigated by several authors in the international marketing literature (Bilkey \& Nes, 1987; Hong \& Wyer, 1989; Kim \& Chung, 1997; Zhou \& Hui, 2003). In 1997, Kim and Chung found that country image affects the impact of marketing variables on sales (Kim \& Chung, 1997). Next, in their groundbreaking work on the subject of Country of Origin, Bilkey and Nes (1987) reach the conclusion that consumers tend to evaluate domestic products more favorably than foreign products. This is logical and may stem from ethnocentric feelings towards one's own country and its corresponding product offering. There is also a trust factor which makes the national brand appear preferable to its domestic consumers (Zhou \& Hui, 2003). When considering large-scale purchases in particular, we expect that country of origin effects may be evident in consumers today. Ultimately, attitudes toward products from a country may vary by industry; therefore, conflicting results are likely across research in different product areas (Bilkey \& Nes, 1987).

A product's $\mathrm{COO}$ stimulates subjects' interest in the product and consequently leads them to think extensively about product information and its evaluative implications (Hong \& Wyer, 1989). That being said, COO is not the attribute upon which consumers ultimately decide on products, it is merely one of many attributes (Hong \& Wyer, 1989). Peterson and Jolibert investigated the COO effect in their 1995 study and found that it is a stronger predictor for quality/reliability perceptions than purchase intentions (Peterson \& Jolibert, 1995). Thus, when thinking about warranty, the $\mathrm{COO}$ of the product will impact the perception of the quality of the warranty. Consumers will spontaneously and actively attempt to confirm the validity of $\mathrm{COO}$ stereotypes as they receive information about specific products from various countries (Hong \& Wyer, 1989).

In terms of large-scale purchases, the $\mathrm{COO}$ effect in the automobile industry was investigated roughly 25 years ago in Johansson, Douglas, and Nonaka's 1985 work. The results of this research project were mixed. On the factor of gas mileage, $\mathrm{COO}$ had a positive impact on overall automobile ratings; however, automobiles receiving high overall ratings tended to be underrated on gas mileage, suggesting that a preferred car would not have good gas mileage (Johansson, Douglas, \& Nonaka, 1985). Further, the COO of an automobile does not seem to affect overall ratings, but has some effects on specific attributes (Johansson et al., 1985). We expect similar results when doing empirical work on this study: that the $\mathrm{COO}$ of a large-scale purchase will play a role in the branding effort, but it will not be the deciding factor in the purchasing decision. We also expect that when the COO effect is moderated by warranty, there will be a greater chance that the domestic customer will be willing to purchase this product. Thus, the following propositions are posited:

- Proposition 5 - The Country of Origin will not be sufficient for making a purchasing decision.

- Proposition 6 - When the Country of Origin Effect is moderated by Warranty, a consumer's willingness to purchase will be increased.

In concluding this brief discussion on $\mathrm{COO}$ and its effects, two main findings will be relied upon moving forward. First, certain countries may have a special advantage in exporting manufactured goods based on their present reputation regarding the product categories (Bilkey \& Nes, 1987), and secondly, brands originating from a particular country share intangible assets that are unique to brands from the same country (Kim \& Chung, 1997).

\subsubsection{Psychic Distance}

The Psychic Distance concept has been defined as an individual's perception of the differences between a home country and a foreign country that shapes the thoughts and feeling towards that country's products or services (Sousa \& Bradley, 2006). Psychic Distance is measured at the individual level and varies on a case-by-case method, hence the root of the term coming from the Greek word for one's mind or soul (Sousa \& Bradley, 2006). 
Much current research has investigated the correlation between psychic distance and a person's ethnocentrism (O'Grady \& Lane 1996; Shimp \& Sharma, 1987). One could reasonably expect that if a consumer who was very ethnocentric had the option between a domestic and a foreign product, he or she would likely choose the domestic product given the ethnocentric viewpoint and low tolerance of cultural distance. Thus, we believe that psychic distance will be a factor in a customer's evaluation of a particular brand.

In their 1996 piece entitled "The Psychic Distance Paradox", authors O'Grady and Lane describe some of the indicators of psychic distance, which will be considered in the empirical portion of this research. It should be noted than many of these indicators are similar to that of Hofstede's dimensions; it is clear that this stream of research was influenced greatly by Cultures and Organizations (Hofstede, 1991). To begin, the level of economic development is an indicator of psychic distance (O'Grady \& Lane, 1996). For example, the distance between the United States (a developed country) and Canada (another developed country) would be less than the difference between the United States and India (a developing country). Therefore, it is expected that a domestic consumer in the United States would have less resistance to buying a product from a similarly categorized economy. Next, level of education is another psychic distance indicator (O'Grady \& Lane, 1996). A consumer considering purchasing an item from a foreign manufacturer may consider this factor and make a generalization of the company's competence based on its national education system. Finally, another indicator has to do with language. This incorporates both national language as well as business language (O'Grady \& Lane, 1996). The language indicator may be confounded by the fact that most major multinational firms have North American presence and thus, they do business comprehensively in English when dealing with American customers. However, since the language factor was found to be a predictor previously, we will investigate it in this study as well. Based on the literature review in psychic distance, we posit the following two hypotheses to be tested in through this research on large-scale purchases:

- Proposition 7 - Psychic Distance will positively or negatively affect the consumer's perception of a brand, depending on the proximity between the purchaser and the foreign brand in terms of education, economic development, and language.

- Proposition 8 - When the Psychic Distance factor is moderated by Warranty, a consumer's willingness to purchase will be increased.

With regard to proposition 8 , we expect that the moderating effect of warranty will parallel the relationship posited in proposition 6 , in the sense that a warranty will be used to offset some of what consumers might perceive as an international risk in purchasing a product from a country dissimilar to the United States.

\subsubsection{National Exposure}

In concluding our discussion on additional branding factors, we expect that the national exposure of a brand will have an impact on the branding effort. One of the first academic teams to research this area was Bellizzi, Kruckeberg, Hamilton, and Martin in 1981. In their study, it was discovered that regardless of actual quality of the items, national brands were rated higher in terms of quality, appearance, and attractiveness (Bellizzi et al., 1981). Several other findings have confirmed their original findings (Cunningham, Hardy, \& Imperia. 1982; Livesey \& Lennon, 1978). To give an example, brands such as Gatorade (Pepsi) and Powerade (Coca-Cola) are given such national exposure via sports advertisements, team apparel, signage at arenas, and sponsorship, that a competing brand not actively engaged in marketing to the national audience (such as PurAqua - a national brand which is sold throughout the US as a "knock-off" to the main competitors - the firm does no advertising) will be met with resistance from the customer due to issues of trust and quality with the unknown brand. Despite the savings or potential quality that can be derived from the unknown brand, the consumer will resist purchasing it nonetheless (Livesey \& Lennon, 1978). Thus, the following proposition is made:

- Proposition 9 - The degree of national exposure a brand is given (as defined by its presence in the media and marketplace) will be positively associated with the attitude/perception effect of the firm.

\section{Proposed Frameworks}

This research project is interested in gaining a better understanding of the impact of warranty on attitudes / perceptions and choice decisions for large-scale purchases. The following frameworks are proposed which illustrate the relationships we anticipate in data collection. Each proposition is identified where it will be examined: 


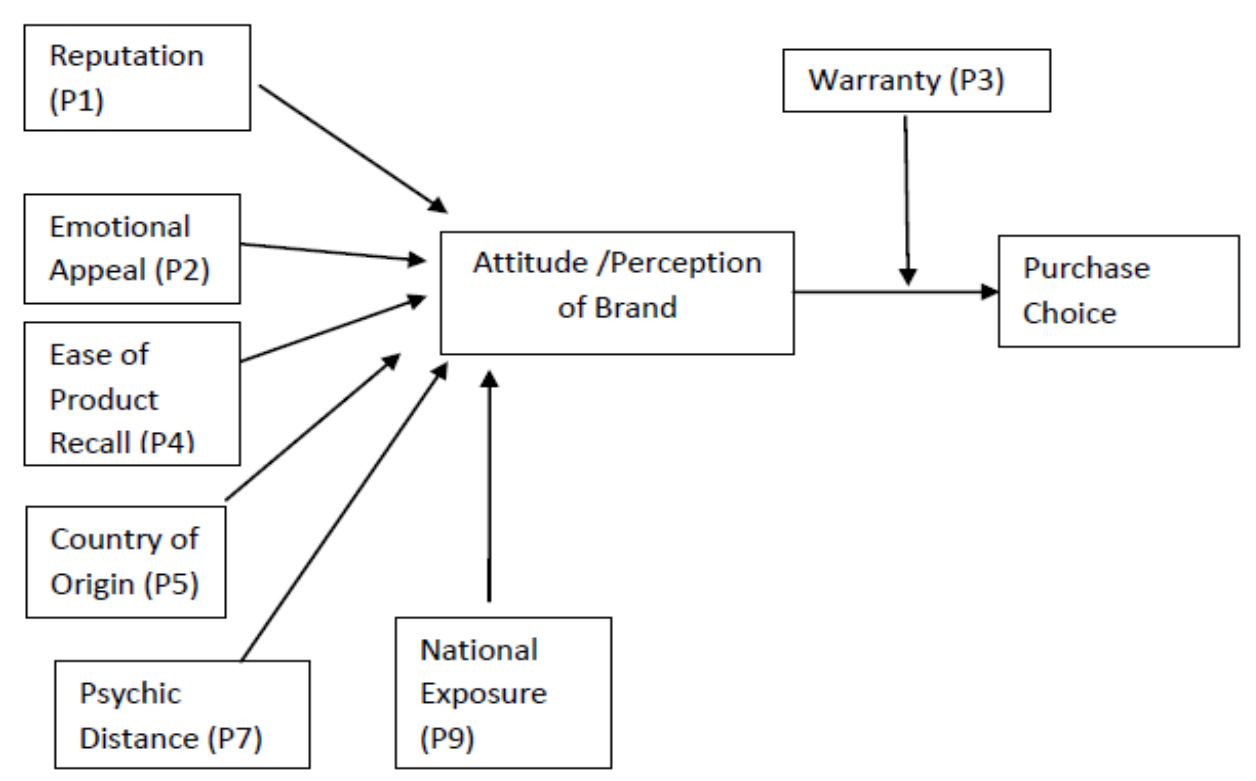

Figure 1. The Moderating Role of Warranty on Purchase Choice

To test the second propositions on both Country of Origin and Psychic Distance (Propositions 6 and 8), the following two frameworks are anticipated to emerge from our empirical study:



Figure 2. Country of Origin and Willingness to Purchase

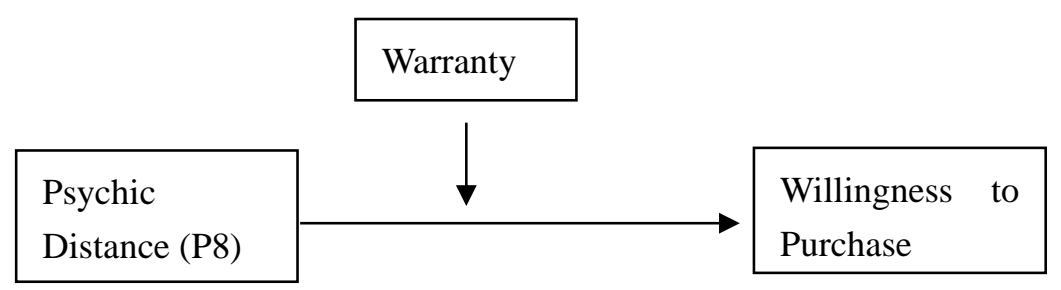

Figure 3. Psychic Distance and Willingness to Purchase

\section{Managerial Implications}

Marketing managers can use the results of this research in many very practical ways. To begin, by gaining a more comprehensive understanding of the impact a warranty has on the consumer's decision-making process, firms will be in a better position to effectively allocate resources to its warranty offering and warranty advertising. Next, for firms from psychically distant countries (compared to the United States), marketing managers can promote their warranty so as to guarantee the claim that their brand's offering will parallel, if not exceed, the expectations from firms in countries that are less psychically distant. For example, since Japan is a developed economy much like the United States, an American customer will place a greater reliance on the Japanese offering since he or she is aware of the country's reputation for high quality as well as the similarities between the two economies and level of education. On the other hand, in countries that do not parallel the United States in terms of economics, language, and education, consumers are likely to meet such product offerings with resistance. The quality of a foreign warranty, in such cases, is proposed to compensate for the lack of proximity in psychic distance. To lessen the impact of psychic distance on large-scale purchases, International marketing 
managers can make efforts in branding by illustrating "taste-test" results much like the classic Coca-Cola and Pepsi example of McClure et al. in 2004.

Managers and firms can also make efforts to help the consumer in their decision making process. As has been illustrated by recent literature (Schwartz, 2004), consumers can many times be completely overwhelmed in the decision making process with all the choices, options, and advertisements seemingly everywhere they look. If firms were to present their offerings in such a way that focuses only on the critical elements of the purchase decision, consumers will be able to approach the decision with a sense of ease and clarity, thus increasing their ability to make a reasonable decision. Naturally, firms will be competing for the same clientele, so managers (particularly marketing managers) will need to be creative so as to distinguish themselves, but not overwhelming so as to fend off potential buyers.

\section{Conclusion}

At the end of the day, a warranty is a critical element of purchasing, particularly with large-scale items. When a consumer risks a large amount of his or her finances on a significant purchase, there are expectations that come along with that purchase decision. Firms can ease the consumer's mind by assuring them that the product will meet or exceed expectations, or the company will rectify the situation to the customer's satisfaction with an effective warranty. Eliciting this ease of mind in the consumer is the critical deliverable of the warranty, and when consumers realize satisfaction either by not experiencing problems or calling upon the warranty to make things right, an emotional relationship can be established between the firm and the customer. This implication pays dividends not only once, but many times via repeat purchases by satisfied, loyal customers. Research has shown that positive past brand experience leads to customer retention and the overall resonance of the brand (Oliver, 1993). Therefore, a warranty can be thought of as a critical component of a product offering that must be managed, fostered, and continually revised so as to meet or exceed customer expectations.

\section{References}

Aaker, D. A. (1991). Managing Brand Equity: Capitalizing on the Value of a Brand Name. New York, NY: The Free Press.

Aaker, D. A., \& Jacobson, R. (1994). The financial information content of perceived quality. Journal of marketing research, 191-201. https://doi.org/ 10.2307/3152193

Alba, J. W., \& Hasher, L. (1983). Is memory schematic? Psychological Bulletin, 93(2), 203. https:doi.org/0033-2909/83/9302-0203

Albaum, G., \& Wiley, J. (2010). Consumer perceptions of extended warranties and service providers. Journal of Consumer Marketing, 27(6), 516-523. https://doi.org/10.1108/07363761011078253

Altonji, J. G., Hayashi, F., \& Kotlikoff, L. J. (1992). Is the extended family altruistically linked? Direct tests using micro data. The American Economic Review, 1177-1198. www.jstor.org/stable/2117473.

America's Greatest Brands. (2010). American Brands Council. Retrieved from: http://www.americasgreatestbrands.com/volume8/\#

Barsalou, L. W. (1985). Ideals, central tendency, and frequency of instantiation as determinants of graded structure in categories. Journal of experimental psychology: learning, memory, and cognition, 11(4), 629. https://doi.org/10.1037/0278-7393.11.1-4.629

Bellizzi, J. A., Krueckeberg, H. F., Hamilton, J. R., \& Martin, W. S. (1981). Consumer perceptions of national, private, and generic brands. Journal of retailing, 57(4), 56-70.

Bilkey, W. J., \& Nes, E. (1982). Country-of-origin effects on product evaluations. Journal of international business studies, 13(1), 89-100. https://doi.org/10.1057/palgrave.jibs.8490539

Blau, P.M. (1964). Exchange and Power in Social Life. New York, NY: John Wiley \& Sons.

Churchill Jr, G. A., \& Surprenant, C. (1982). An investigation into the determinants of customer satisfaction. Journal of marketing research, 491-504. https:doi.org/10.2307/3151722

Coleman, J. S. (1988). Social capital in the creation of human capital. American journal of sociology, 94, S95-S120. http://www.jstor.org/stable/2780243

Cox, D., \& Rank, M. R. (1992). Inter-vivos transfers and intergenerational exchange. The review of economics and statistics, 305-314. http://www.jstor.org/stable/2109662

Cunningham, I. C., Hardy, A. P., \& Imperia, G. (1982). Generic brands versus national brands and store brands. Journal of Advertising Research, 22(5), 25-32. 
Day, E., \& Fox, R. J. (1985). Extended Warranties, Service Contracts, and Maintenance Agreements-A Marketing Opportunity? Journal of Consumer Marketing, 2(4), 77-86. https://doi.org/10.1108/eb008148

George, L. K. (1998). Rational choice theories: Contributions and limitations. Journal of Financial Service Professionals, 52(5), 32.

Gigerenzer, G., \& Goldstein, D. G. (1996). Reasoning the fast and frugal way: models of bounded rationality. Psychological review, 103(4), 650. http://dx.doi.org/10.1037/0033-295X.103.4.650

Gigerenzer, G., \& Selten, R. (Eds.). (2002). Bounded rationality: The adaptive toolbox. MIT press.

Hess Jr, R. L. (2008). The impact of firm reputation and failure severity on customers' responses to service failures. Journal of Services Marketing, 22(5), 385-398. https://doi.org/10.1108/08876040810889157

Hirschman, E. C., \& Holbrook, M. B. (1982). Hedonic consumption: emerging concepts, methods and propositions. The Journal of Marketing, 92-101. https://doi.org/10.2307/1251707

Hofstede, G. (1991). Cultures and Organizations: Software of the Mind. Berkshire, UK: McGraw Hill.

Hong, S. T., \& Wyer Jr, R. S. (1989). Effects of country-of-origin and product-attribute information on product evaluation: An information processing perspective. Journal of Consumer Research, 16(2), 175-187. https://doi.org/10.1086/209206

Johansson, J. K., Douglas, S. P., \& Nonaka, I. (1985). Assessing the impact of country of origin on product evaluations: a new methodological perspective. Journal of Marketing Research, 388-396. https://doi.org/10.2307/3151584

Johnson, D., \& Grayson, K. (2005). Cognitive and affective trust in service relationships. Journal of Business research, 58(4), 500-507. https://doi.org/10.1016/S0148-2963(03)00140-1

Kahneman, D., \& Miller, D. T. (1986). Norm theory: Comparing reality to its alternatives. Psychological review, 93(2), 136. http://dx.doi.org/10.1037/0033-295X.93.2.136

Keeney, R. L., \& Raiffa, H. (1993). Decisions with multiple objectives. Cambridge, England: Cambridge University Press. https://doi.org/10.1017/CBO9781139174084

Keller, K. L. (2003). Strategic Brand Management: Building, Measuring, and Managing Brand Equity (2 $2^{\text {nd }}$ ed.). Upper Saddle River, NJ: Prentice Hall.

Kelley, C. A., \& Conant, J.S. (1987). Extended Warranties: An Exploratory Study of Consumer Behavior, AMA Educators' Proceedings, Series No. 53, Chicago: AMA.

Kim, C. K., \& Chung, J. Y. (1997). Brand popularity, country image and market share: an empirical study. Journal of International Business Studies, 28(2), 361-386. https://doi.org/10.1057/palgrave.jibs.8490105

Kintsch, W., \& Young, S. R. (1984). Selective recall of decision-relevant information from texts. Memory \& cognition, 12(2), 112-117. https://doi.org/10.3758/BF03198424

Livesey, F., \& Lennon, P. (1978). Factors affecting consumers' choice between manufacturer brands and retailer own labels. European Journal of Marketing, 12(2), 158-170. https://doi.org/10.1108/EUM0000000004965

Lopes, L. L. (1992). Three misleading assumptions in the customary rhetoric of the bias literature. Theory \& Psychology, 2(2), 231-236. https://doi.org/10.1177/0959354392022010

Low, G. S., \& Lamb Jr, C. W. (2000). The measurement and dimensionality of brand associations. Journal of Product \& Brand Management, 9(6), 350-370. https://doi.org/10.1108/10610420010356966

McClure, S. M., Li, J., Tomlin, D., Cypert, K. S., Montague, L. M., \& Montague, P. R. (2004). Neural correlates of behavioral preference for culturally familiar drinks. Neuron, 44(2), 379-387. https://doi.org/10.1016/j.neuron.2004.09.019

Mitchell, A. A., \& Olson, J. C. (1981). Are product attribute beliefs the only mediator of advertising effects on brand attitude? Journal of Marketing Research, 318-332. https://www.jstor.org/stable/3150973

Nedungadi, P. (1990). Recall and consumer consideration sets: Influencing choice without altering brand evaluations. Journal of consumer research, 17(3), 263-276. https://doi.org/10.1086/208556

Noel, C. P. (2001). More coverage with that? Consumers seldom benefit from extended warranties. Christian Science Monitor, October, 15.

O'grady, S., \& Lane, H. W. (1996). The psychic distance paradox. Journal of international business studies, 27(2), 309-333. https://doi.org/10.1057/palgrave.jibs.8490137 
Oliver, R. L. (1993). Cognitive, affective, and attribute bases of the satisfaction response. Journal of consumer research, 20(3), 418-430. https://doi.org/10.1086/209358

Padmanabhan, V., \& Rao, R. C. (1993). Warranty policy and extended service contracts: Theory and an application to automobiles. Marketing Science, 12(3), 230-247. https://doi.org/10.1287/mksc.12.3.230

Peterson, R. A., \& Jolibert, A. J. (1995). A meta-analysis of country-of-origin effects. Journal of International business studies, 26(4), 883-900. https://doi.org/10.1057/palgrave.jibs.8490824

Petty, R. E., Cacioppo, J. T., \& Schumann, D. (1983). Central and peripheral routes to advertising effectiveness: The moderating role of involvement. Journal of consumer research, 10(2), 135-146. https://doi.org/10.1086/208954

Roberts, K. (2004). Lovemarks: The Future Beyond Brands. New York, NY: Powerhouse Books.

Rooney, J. A. (1995). Branding: a trend for today and tomorrow. Journal of product \& brand management, 4(4), 48-55. https://doi.org/10.1108/10610429510097690

Sandom, J. (2008). Packaging is rubbish. Or is it. Marketing, 20-21.

Schwartz, B. (2004). The paradox of choice: Why more is less. New York: Ecco.

Sethuraman, R., \& Cole, C. (1997). Why do consumers pay more for national brands than for store brands? Report-marketing science institute cambridge, massachusetts.

Shimp, T. A., \& Sharma, S. (1987). Consumer ethnocentrism: Construction and validation of the CETSCALE. Journal of marketing research, 280-289. https://doi.org/10.2307/3151638

Shuptrine, F. K., \& Moore, E. M. (1980). Even After the Magnuson - Moss Act of 1975, Warranties Are Not Easy to Understand. Journal of Consumer Affairs, 14(2), 394-404. https://doi.org/10.1111/j.1745-6606.1980.tb00677.x

Simon, H. A. (1955). A behavioral model of rational choice. The quarterly journal of economics, 69(1), 99-118. https://doi.org/10.2307/1884852

Simon, H. A. (1957). Models of man: social and rational; mathematical essays on rational human behavior in society setting. New York, NY: Wiley.

Snow, D. A., \& Oliver, P. E. (1995). Social movements and collective behavior: Social psychological dimensions and considerations. Sociological perspectives on social psychology, 571-99.

Sousa, C. M., \& Bradley, F. (2006). Cultural distance and psychic distance: two peas in a pod? Journal of International Marketing, 14(1), 49-70. https://doi.org/10.1509/jimk.14.1.49

Story, L. (2007). Anywhere the eye can see, it's likely to see an ad. The New York Times, p.15.

Tversky, A., \& Kahneman, D. (1986). Rational choice and the framing of decisions. Journal of business, S251-S278. https://doi.org/10.1086/296365

Tversky, A., \& Simonson, I. (1993). Context-dependent preferences. Management science, 39(10), 1179-1189. https://doi.org/10.1287/mnsc.39.10.1179

Voss, G. B., \& Ahmed, I. (1992). Extended warranties: a behavioral perspective. ACR North American Advances. http://acrwebsite.org/volumes/7405/volumes/v19/NA-19

Walvis, T. H. (2008). Three laws of branding: Neuroscientific foundations of effective brand building. Journal of Brand Management, 16(3), 176-194. https://doi.org/10.1057/palgrave.bm.2550139

Xie, W. (2017). Optimal pricing and two-dimensional warranty policies for a new product. International Journal of Production Research, 55(22), 6857-6870. https://doi.org/10.1080/00207543.2017.1355578

Zeithaml, V. A. (1988). Consumer perceptions of price, quality, and value: a means-end model and synthesis of evidence. The Journal of marketing, 2-22. https://doi.org/ 10.2307/1251446

Zhou, L., \& Hui, M. K. (2003). Symbolic value of foreign products in the People's Republic of China. Journal of International Marketing, 11(2), 36-58. https://doi.org/10.1509/jimk.11.2.36.20163

\section{Copyrights}

Copyright for this article is retained by the author(s), with first publication rights granted to the journal.

This is an open-access article distributed under the terms and conditions of the Creative Commons Attribution license (http://creativecommons.org/licenses/by/4.0/). 